\title{
FORMATION OF $\gamma^{\prime}-\mathrm{Ni}_{3} \mathrm{AI}$ VIA THE PERITECTOID REACTION: $\gamma+\beta\left(+\mathbf{A l}_{2} \mathbf{O}_{3}\right)=\gamma^{\prime}\left(+\mathrm{Al}_{2} \mathrm{O}_{3}\right)$
}

\author{
Evan Copland ${ }^{1}$ \\ ${ }^{1}$ Case Western Reserve University, Cleveland, Ohio 44135
}

nickel aluminides: solidification: partial thermodynamic properties: Knudsen effusion mass spectrometry

\begin{abstract}
The activities of $\mathrm{Al}$ and $\mathrm{Ni}$ were measured using multi-cell Knudsen effusion-cell mass spectrometry (multi-cell KEMS), over the composition range $8-32$ at.\% $\mathrm{Al}$ and temperature range $T=1400-1750 \mathrm{~K}$ in the Ni-Al-O system. These measurements establish that equilibrium solidification of $\gamma^{\prime}-\mathrm{Ni}_{3} \mathrm{Al}$-containing alloys occurs by the eutectic reaction, $L\left(+\mathrm{Al}_{2} \mathrm{O}_{3}\right)=\gamma+\beta(+$ $\mathrm{Al}_{2} \mathrm{O}_{3}$ ), at $1640 \pm 1 \mathrm{~K}$ and a liquid composition of $24.8 \pm 0.2$ at. $\% \mathrm{Al}$ (at an unknown oxygen content). The $\left\{\gamma+\beta+\mathrm{Al}_{2} \mathrm{O}_{3}\right\}$ phase field is stable over the temperature range $1633-1640 \mathrm{~K}$, and $\gamma^{\prime}-\mathrm{Ni}_{3} \mathrm{Al}$ forms via the peritectiod, $\gamma+\beta\left(+\mathrm{Al}_{2} \mathrm{O}_{3}\right)=\gamma^{\prime}(+$ $\mathrm{Al}_{2} \mathrm{O}_{3}$ ), at $1633 \pm 1 \mathrm{~K}$. This behavior is inconsistent with the current $\mathrm{Ni}-\mathrm{Al}$ phase diagram and a new diagram is proposed. This new Ni-Al phase diagram explains a number of unusual steadystate solidification structures reported previously and provides a much simpler reaction scheme in the vicinity of the $\gamma^{\prime}-\mathrm{Ni}_{3} \mathrm{Al}$ phase field.
\end{abstract}

\section{Introduction}

The Ni-Al system is the foundation for Ni-base superalloys used in gas-turbine applications. The precipitation of $\gamma^{\prime}-\mathrm{Ni}_{3} \mathrm{Al}$ (ordered FCC, $\mathrm{L1}_{2}$ ) from $\gamma$-(Ni) (disordered FCC) gives these alloys their remarkable high temperature mechanical properties. To fully understand these alloys the equilibrium phase boundaries and solution behavior of $\gamma$-(Ni), $\gamma^{\prime}-\mathrm{Ni}_{3} \mathrm{Al}, \beta-\mathrm{NiAl}$ (ordered cubic, B2) and liquid, $L$, phases need to be accurately determined in the composition range $10-35$ at.\% Al. This need is widely recognized as shown by the large number of detailed experimental studies $^{[1-18]}$, assessed phase diagrams ${ }^{[19-21]}$ and various thermodynamic models ${ }^{[22-25]}$ published over the last 70 years. The solidification behavior of $\gamma^{\prime}-\mathrm{Ni}_{3} \mathrm{Al}$ and the $\mathrm{Ni}-\mathrm{Al}$ phase diagram has been modified a number of times over this period, but the consensus has been $\gamma^{\prime}-\mathrm{Ni}_{3} \mathrm{Al}$ remains stable up to the liquidus and is involved in both eutectic and peritectic transformations. To date much of the discussion has focused on which side of $\gamma^{\prime}-\mathrm{Ni}_{3} \mathrm{Al}$ and at what temperature the invariant reactions exist.

It is important to note the transformation from $\gamma-(\mathrm{Ni})$ and $\beta-\mathrm{NiAl}$ to $\gamma^{\prime}-\mathrm{Ni}_{3} \mathrm{Al}$ is fast ${ }^{[4-8,12-15,17]}$ and the $\gamma^{\prime}-\mathrm{Ni}_{3} \mathrm{Al}$ phase field broadens significantly and growth of new $\gamma^{\prime}-\mathrm{Ni}_{3} \mathrm{Al}$ consumes the eutectic and peritectic microstructures on cooling ${ }^{[4,8,19-21]}$. As a result it is difficult to quench-in the high-temperature microstructures of $\gamma^{\prime}$ $\mathrm{Ni}_{3} \mathrm{Al}$ containing alloys and observe them at room temperature. Experimental techniques that provide information about the phase equilibria at temperature are therefore crucial to studying the NiAl system. Many studies of this system have used directional solidification (DS), differential thermal analysis (DTA) and differential scanning calorimetry (DSC) techniques to study the high temperature phase equilibria, but it is always hard to determining equilibrium transformation temperatures or phase boundaries under non-isothermal or irreversible conditions. DS involves significant thermal gradient and heat flux across the solidification front, while DTA and DSC studies involve heating and cooling rates of $2.0 \sim 10 \mathrm{~K} / \mathrm{min}$. DS provides important information about steady-state solidification in these alloys, but a number of studies report a range of microstructures that that are unexplainable with the current $\mathrm{Ni}-\mathrm{Al}$ phase diagram (e.g., $\beta+\gamma$ eutectics and unusual $\gamma^{\prime} / \gamma^{\prime}$ interfaces $)^{[12-16]}$. Reducing the ramping rate of DTA and DSC give closer to equilibrium transformations but reduced signal intensity imposes a low limit on the ramp rate ${ }^{[30]}$. Of more concern is the disagreement between transformation temperatures observed during heating and cooling ( up to $20 \sim 100 \mathrm{~K}$ ), which was the major reason sighted by Hilpert for including KEMS measurements in their studies ${ }^{[8,9]}$. The KEMS technique is well suited to study equilibrium solidification behavior because isothermal conditions are obtained ( $T$ is routinely held within $\pm 0.5 \mathrm{~K}$ over $1-4 \mathrm{hrs}$ ) and equilibrium is closely approached. Equilibrium transformations are determined by extrapolating measured equilibrium behavior on either side of a phase boundary or transformation ${ }^{[27,28]}$.

Another aspect that is not always adequately considered is the thermodynamic state of the system present in these experiments. To correctly interpret thermodynamic property measurements the equilibrium needs to be described accurately and any unmeasured variables must be identified and all assumptions clearly stated. The typical approach has been to only consider the Ni-Al alloy and ignore the container material (typically $\mathrm{Al}_{2} \mathrm{O}_{3}$ ). In this study the boundary of the system is identified as the inner surface of the effusion-cell and $\mathrm{Al}_{2} \mathrm{O}_{3}$ is included together with the alloy sample, thus the alloy $+\mathrm{Al}_{2} \mathrm{O}_{3}+$ vapor \} equilibrium describes the thermodynamic state and the Ni-Al-O ternary system is considered $^{[29,31,32]}$. In these equilibria the alloy phases $\gamma$-(Ni), $\gamma^{\prime}$ $\mathrm{Ni}_{3} \mathrm{Al}, \beta-\mathrm{NiAl}$ and $L$ are saturated with $\mathrm{O}$, and the $\mathrm{Al}_{2} \mathrm{O}_{3}$ is saturated with $\mathrm{Al}$ and $\mathrm{Ni}$ from the alloy. The amount of $\mathrm{O}$ saturation in the alloy and $\mathrm{Ni}$ and $\mathrm{Al}$ in $\mathrm{Al}_{2} \mathrm{O}_{3}$ are unknown. This removes the implicit assumptions that dissolved $\mathrm{O}$ does not influence the solution behavior of the alloy phases and measurements made in the Ni-Al-O system can be applied directly to the Ni-Al system. A review of the phase equilibrium observed in the $\mathrm{Al}-\mathrm{O}^{[33]}$ and $\mathrm{Ni}-\mathrm{O}^{[34]}$ systems clearly shows the merit of including $\mathrm{O}$ and $\mathrm{Al}_{2} \mathrm{O}_{3}$ in the description of the results and considering them in terms of the ternary system. This paper reports a series of partial thermodynamic property measurements ( activities of $a(\mathrm{Al})$ and $a(\mathrm{Ni}))$ made by the vapor pressure method with a multiple Knudsen effusion cell mass spectrometer (multicell KEMS) in Ni-Al alloys in equilibrium with $\mathrm{Al}_{2} \mathrm{O}_{3}$. Particular attention is given to compositions on either side of $\gamma^{\prime}-\mathrm{Ni}_{3} \mathrm{Al}$, nominally Ni-23at.\%Al and Ni-27at.\%Al in the $\left\{\gamma^{\prime}+\gamma+\mathrm{Al}_{2} \mathrm{O}_{3}\right\}$ and $\left\{\gamma^{\prime}+\beta+\mathrm{Al}_{2} \mathrm{O}_{3}\right\}$ condensed three-phase fields, respectively. These measurements raise some fundamental questions about the accepted solidification behavior of $\gamma^{\prime}-\mathrm{Ni}_{3} \mathrm{Al}$, which are considered in detail. 


\section{Experimental}

\section{Alloy and Sample Preparation}

The alloys considered in this study are listed in Table 1. Their compositions were determined by inductively coupled plasma spectroscopy (using a Varian Vista-Pro ICP-OES) and inert gas fusion for nitrogen / oxygen (using a LECO TC-436). All alloys were prepared by repeated arc-melting ( 5 times) the correct proportions of the pure elements (at least $99.995 \mathrm{wt} \% \%$ pure) and cast in water-cooled copper molds. After casting all alloys were homogenized in a flowing argon gas atmosphere at $1473 \mathrm{~K}$ for 6 hours and at $1423 \mathrm{~K}$ for an additional 24 hours, water quenched and cut into 1 to $2 \mathrm{~mm}$ thick slices. Directly prior to loading into the effusion cell (and pumping to $10^{-4} \mathrm{~Pa}$ ) the surface of each alloy slice was removed by grinding with 600 -grit $\mathrm{SiC}$ paper, roughly cut into $2 \mathrm{~mm}$ cubes with a metal shear and ultrasonically cleaned in acetone then ethanol. Typically, $0.7 \sim 1.5 \mathrm{~g}$ of alloy sample was loaded into each effusion cell. The effusion cells were fabricated from high purity polycrystalline $\mathrm{Al}_{2} \mathrm{O}_{3}$ (at least $99.5 \mathrm{wt} \%$ pure). Prior to these experiments the effusion cells were used numerous times with similar $\mathrm{Ni}-\mathrm{Al}$ alloys and were cleaned between each use by soaking in hot aqua regia $\left(\mathrm{HNO}_{3}\right.$ : $\mathrm{HCl}, 1: 3)$ and baking in the temperature range, $T=1800-1850 \mathrm{~K}$ under vacuum $\left(\sim 10^{-3} \mathrm{~Pa}\right)$ for $10-12$ hours.

Table 1. Measured Alloy Composition (at.\%)

\begin{tabular}{|c|c|c|c|c|}
\hline Alloy & $\mathrm{Ni}$ & $\mathrm{Al}$ & $\mathrm{O}$ & $\Sigma \mathrm{Cr}, \mathrm{Cu}, \mathrm{Fe}, \mathrm{Mn}, \mathrm{Ti}$ \\
\hline $\mathrm{Ni}-8 \mathrm{Al}{ }^{\mathrm{a}}$ & 91.69 & 8.30 & 0.010 & $\sim$ \\
\hline $\mathrm{Ni}-15 \mathrm{Al}^{\mathrm{c}}$ & 84.83 & 15.16 & 0.004 & 0.007 \\
\hline $\mathrm{Ni}-20 \mathrm{Al}{ }^{\text {a }}$ & 80.17 & 19.81 & 0.009 & 0.004 \\
\hline $\mathrm{Ni}-23 \mathrm{Al}{ }^{\mathrm{b}}$ & 76.64 & 23.34 & 0.005 & 0.016 \\
\hline $\mathrm{Ni}-25 \mathrm{Al}{ }^{\mathrm{b}}$ & 74.61 & 25.38 & 0.004 & 0.003 \\
\hline $\mathrm{Ni}-27 \mathrm{Al}{ }^{\mathrm{b}}$ & 72.72 & 27.26 & 0.007 & 0.012 \\
\hline $\mathrm{Ni}-29 \mathrm{Al}^{\mathrm{a}}$ & 70.23 & 29.76 & 0.008 & 0.002 \\
\hline $\mathrm{Ni}-30 \mathrm{Al}^{\mathrm{b}}$ & 69.63 & 30.35 & 0.012 & 0.009 \\
\hline $\mathrm{Ni}-32 \mathrm{Al}^{\mathrm{a}}$ & 67.6 & 32.4 & 0.006 & $\sim$ \\
\hline
\end{tabular}

fabricated by: a) NASA Glenn Research Center, b) Materials Preparation Center, Ames Laboratory, c) Air Force Research Laboratory-ML

\section{Activity and Phase Equilibrium Measurements}

The activities of $\mathrm{Al}$ and $\mathrm{Ni}$ in the various alloy $+\mathrm{Al}_{2} \mathrm{O}_{3}$ \} equlibria were determined by the vapor pressure method, where the partial pressure of characteristic vapor species, $\mathrm{Al}(\mathrm{g})$ and $\mathrm{Ni}(\mathrm{g})$, in equilibrium with each sample, $p(\mathrm{i})$, are compared to a reference state, $p^{\mathrm{o}}(\mathrm{i})$, according to: $a(\mathrm{i})=p(\mathrm{i}) / p^{\mathrm{o}}(\mathrm{i})^{[35-37]}$. The partial pressures were determined as a function of temperature by Knudsen effusion-cell mass spectrometry, KEMS, where $p(i)$ inside the effusion-cell is determined from the measured intensity of a representative ion beam, $I_{\mathrm{i}}$, and absolute temperature, $T$, according to the relationship: $p(\mathrm{i})=I_{\mathrm{i}} T / S_{\mathrm{i}} \quad$ (where $S_{\mathrm{i}}$ is the instrument sensitivity factor $)^{[38]}$. The need to determine $S_{\mathrm{i}}$ and absolute partial pressure was removed in this study with a multiple effusion-cell vapor source (with three effusion-cells), multi-cell KEMS, which allows the relative partial pressure between samples in adjacent effusion-cells to be determined directly ${ }^{[39-42]}$. These measurements are made effectively independent of the effusion-cell by introducing two fixed apertures between the effusion-cell and ion-source (which define the molecular beam) together with consistent alignment of each effusion-cell orifice with these fixed apertures. The multi-cell vapor source allows two alloys and pure- $\mathrm{Au}(\mathrm{s}, \mathrm{l})$, as a secondary reference, to be measured in a single experiment with an indirect procedure, represented by Eq. 1. Activities are determined at each temperature, $T$, by comparing the ratio of the measured relative partial pressure of the characteristic vapor species $(p(\mathrm{Al})$ and $p(\mathrm{Ni}))$ in equilibrium with the sample over $p^{\circ}(\mathrm{Au})$ in equilibrium with pure-Au(s,1), $p(\mathrm{i}) / p^{\mathrm{o}}(\mathrm{Au})$ or $I_{\mathrm{i}} / I_{\mathrm{Au}}^{\mathrm{o}}$, to the tabulated ratio of $p^{\circ}(\mathrm{Au})$ over the characteristic vapor species in equilibrium with the pure-element reference state $p^{\mathrm{o}}(\mathrm{i}),\left[p^{\mathrm{o}}(\mathrm{Au}) / p^{\mathrm{o}}(\mathrm{i})\right]$.

$a(\mathrm{i})=\frac{p(\mathrm{i})}{p^{\circ}(\mathrm{Au})} \cdot\left[\frac{p^{\circ}(\mathrm{Au})}{p^{\circ}(\mathrm{i})}\right]=\frac{I_{\mathrm{i}}}{I_{\mathrm{Au}}^{\circ}} \cdot \frac{\mathrm{S}_{\mathrm{Au}}}{\mathrm{S}_{\mathrm{i}}} \cdot \frac{g_{\mathrm{Au}}}{g_{\text {alloy }}} \cdot\left[\frac{p^{\circ}(\mathrm{Au})}{p^{\circ}(\mathrm{i})}\right]$

The $g_{\mathrm{Au}} / g_{\text {alloy }}$ term accounts for variations in the effusion-orifices for a pair of cells ${ }^{[43-45]}$ and was routinely measured to be $1.00 \pm$ 0.01 in this study. The $\mathrm{S}_{\mathrm{Au}} / \mathrm{S}_{\mathrm{i}}$ terms can be considered as instrument specific ionization cross-section ratios that relate the secondary reference, pure- $\mathrm{Au}(\mathrm{s}, 1)$ or $p^{\circ}(\mathrm{Au})$, to the pure-element references, which are $\left\{\mathrm{Al}(\mathrm{l})+\mathrm{Al}_{2} \mathrm{O}_{3}(\mathrm{~s})\right\}$ or $p^{\circ}(\mathrm{Al})$ and $\{\mathrm{Ni}(\mathrm{s}, \mathrm{l})+$ $\left.\mathrm{Al}_{2} \mathrm{O}_{3}(\mathrm{~s})\right\}$ or $p^{\circ}(\mathrm{Ni})$, respectively. These calibration factors, $\mathrm{S}_{\mathrm{Au}} /$ $\mathrm{S}_{\mathrm{Al}}$ and $\mathrm{S}_{\mathrm{Au}} / \mathrm{S}_{\mathrm{Ni}}$, were measured in separate experiments as 0.154 \pm 0.005 and $0.85 \pm 0.03$, respectively and were independent of temperature. The tabulated ratio $\left[p^{\circ}(\mathrm{Au}) / p^{\circ}(\mathrm{i})\right]$ in Eq. 1 was determined at each $T$ by the $3^{\text {rd }}$-law treatment suggested by Paule ${ }^{[46]}$ using the Gibbs free energy functions for the pure substances from reference 47 together with the measured $2^{\text {nd }}$-law reactions enthalpies listed in column 2 of Table 2. Because of the different ionization efficiency curves for $\mathrm{Au}(\mathrm{g}), \mathrm{Al}(\mathrm{g})$ and $\mathrm{Ni}(\mathrm{g})$ the same electron energy $(25 \mathrm{eV})$ was used for both $\mathrm{S}_{\mathrm{Au}} / \mathrm{S}_{\mathrm{i}}$ and the alloy measurements.

Table 2. Reaction Enthalpies (298K) involving: $\mathrm{Au}(\mathrm{g}), \mathrm{Ni}(\mathrm{g}), \mathrm{Al}(\mathrm{g})$ and $\mathrm{Al}_{2} \mathrm{O}(\mathrm{g})$

\begin{tabular}{ccc} 
Reaction & $\begin{array}{c}\text { Measured } \\
\left(\mathrm{kJmol}^{-1}\right)\end{array}$ & $\begin{array}{c}\text { TPIS } \\
\left(\mathrm{kJmol}^{-1}\right)\end{array}$ \\
\hline $\mathrm{Au}(\mathrm{s}, \mathrm{l})=\mathrm{Au}(\mathrm{g})$ & $363.5 \pm 2.8$ & $367.0 \pm 0.9^{[46]}$ \\
$\mathrm{Ni}(\mathrm{s})=\mathrm{Ni}(\mathrm{g})$ & $367.0 \pm 1.3^{*}$ & \\
$\mathrm{Al}(\mathrm{s})=\mathrm{Al}(\mathrm{g})$ & $428.3 \pm 2.6$ & $428.0 \pm 8.0$ \\
$4 / 3 \mathrm{Al}(\mathrm{s})+1 / 3 \mathrm{Al}_{2} \mathrm{O}_{3}(\mathrm{~s})=\mathrm{Al}_{2} \mathrm{O}(\mathrm{g})$ & $341.0 \pm 2.2$ & $330.0 \pm 3.0$ \\
$4 / 3 \mathrm{Al}(\mathrm{g})+1 / 3 \mathrm{Al}_{2} \mathrm{O}_{3}(\mathrm{~s})=\mathrm{Al}_{2} \mathrm{O}(\mathrm{g})$ & $-41.1 \pm 3.2$ & $-30.0 \pm 4.3$ \\
$2 \mathrm{Al}(\mathrm{g})+\mathrm{O}(\mathrm{g})=\mathrm{Al}_{2} \mathrm{O}(\mathrm{g})$ & $-1075.5 \pm 9.0$ & $-1057.8 \pm 20.0$ \\
${ }^{*} 3^{\text {rd }}$ law measurement & &
\end{tabular}

The multi-cell KEMS configuration also allows relative activities between two compositions, $A$ relative to $B$, to be determined directly by measuring the relative partial pressure in equilibrium with the different samples in adjacent effusion-cells according to: $a(\mathrm{i})_{A-B}=p(\mathrm{i})_{A} / p(\mathrm{i})_{B}=I_{\mathrm{i}}^{A} g^{B} / I_{\mathrm{i}}^{B} g^{A}$. Again, the effect of variations in the effusion orifices were found to be minimal (i.e., $\left.g^{B} / g^{A}=1.00 \pm 0.01\right)$. Relative activities are a direct measure of the change in solution behavior and phase equilibrium between two compositions and remove any error from the thermodynamic properties of the pure-element reference states. In this study relative activity measurements focused on compositions $\mathrm{Ni}-23 \mathrm{Al}$ and Ni-27Al, either side of $\gamma^{\prime}-\mathrm{Ni}_{3} \mathrm{Al}$ in the $\left\{\gamma^{\prime}+\gamma+\mathrm{Al}_{2} \mathrm{O}_{3}\right\}$ and $\left\{\gamma^{\prime}\right.$ $\left.+\beta+\mathrm{Al}_{2} \mathrm{O}_{3}\right\}$ three phase fields. In addition, a change in phase stability (phase boundary) is indicated by a change in the slope in a plot of the logarithm of $a(\mathrm{i})$ versus $1 / T$, for both $\mathrm{Al}$ and $\mathrm{Ni}$. The sensitivity of this measurement is improved by observing the ratio of the ion-intensities, $I_{\mathrm{Ni}} / I_{\mathrm{Al}}$, in the molecular beam from a single 
effusion-cell with temperature ${ }^{[49,50]}$. This technique was used to determine the phase boundaries and temperature of invariant reactions in this study.

The temperature was measured with a pyrometer (Mikron M190V-TS) sighting a blackbody source $(2.5 \mathrm{~mm}$ in diameter and $13.5 \mathrm{~mm}$ long) machined into the bottom of each effusion-cell and Mo-cell holder. Pure-Au(s,l) provides a primary temperature standard. The melting temperature of $\mathrm{Au}, T_{\mathrm{mp}}=1337.33 \mathrm{~K}$, which was used to calibrate the pyrometer in each experiment and the enthalpy of the sublimation of pure- $\mathrm{Au}(\mathrm{s}, 1)$ provided a systematic method of checking the accuracy of these results. The steady state or equilibrium condition in each effusion-cell was verified at each temperature with repeat measurements 30-45 minutes apart. The typical variation in temperature and ion-intensity between repeat measurements was less than $0.5 \mathrm{~K}$ and $1 \%$, respectively. Measurements were made at a range of temperatures over three days and were taken in a random order.

\section{Results}

This publication reports the results from thirteen separate experiments. In each experiment the enthalpy of sublimation of pure- $\mathrm{Au}(\mathrm{s}, 1), \Delta \mathrm{H}_{\text {sub }} \mathrm{Au}(298)$, was determined and used as a check for consistent measurement procedure. In all cases the $2^{\text {nd }}$ and $3^{\text {rd }}$ law values were within the range $362.8 \pm 3.0 \mathrm{kJmol}^{-1}$ and $367.8 \pm 1.0 \mathrm{kJmol}^{-1}$, respectively, and agree with the values listed in Table 2. The activities of $\mathrm{Al}$ and $\mathrm{Ni}$ of all nine alloys are plotted as the logarithm of activity versus $1 / T$ and are shown in Figs. 1 and 2, respectively. For the composition range $8-32$ at.\% $\mathrm{Al}$, the $\mathrm{Al}$ activity varied by about a factor of 300 while the $\mathrm{Ni}$ activity varied by about a factor of 2 . The relative errors in both sets of data are similar, however, the different scales make the $a(\mathrm{Al})$ data look more precise then $a(\mathrm{Ni})$ data. The sensitivity of these measurements to changes in sample composition relates directly to the Gibbs free-energy surface, in this case a difference of 1 at. $\% \mathrm{Al}$ is observable. In Figs. 1 and 2 the univariant phase fields, $\left\{\right.$ phase $^{\mathrm{I}}+$ phase $\left.^{\mathrm{II}}+\mathrm{Al}_{2} \mathrm{O}_{3}\right\}$, in the Ni-Al-O system exist as lines and are identified by solid-lines labeled with stable alloy phases $\gamma^{\prime}+\gamma, \gamma^{\prime}+\beta, \gamma+\beta, L+\gamma$ and $L+\beta$. In regions where bivariant phase fields phase $+\mathrm{Al}_{2} \mathrm{O}_{3}$ \} exist the behavior of each sample is identified by a dashed line and the stable alloy phase is identified. In the univariant phase fields the composition of the condensed phases are fixed but unknown, while in the bivariant fields the composition of the alloy phase is known (oxygen content is unknown) and listed in Table 1.

In Fig. 1 and 2 the changes in slope observed in a particular plot correspond to the sample crossing a phase boundary, in this way these results provide important information about the equilibrium phase boundaries and invariant transformations in the Ni-Al-O system. The most striking feature of these results is the four univariant phase fields $\left(\gamma^{\prime}+\gamma, \gamma^{\prime}+\beta, L+\gamma\right.$ and $\left.L+\beta\right)$ converge somewhere in the temperature range, $T=1630 \sim 1640 \mathrm{~K}$, where the same $\mathrm{Al}$ and $\mathrm{Ni}$ activities were measured for $\mathrm{Ni}-23 \mathrm{Al}, \mathrm{Ni}-$ $25 \mathrm{Al}$ and $\mathrm{Ni}-27 \mathrm{Al}$ samples (note: $a(\mathrm{Al}) \neq a(\mathrm{Ni})$ ). The convergence of the $\gamma^{\prime}+\gamma$ and $\gamma^{\prime}+\beta$ and the subsequent divergence of the $L+\gamma$ and $L+\beta$ univariant phase fields is due to changes in the composition of $\gamma-(\mathrm{Ni}), \gamma^{\prime}-\mathrm{Ni}_{3} \mathrm{Al}, \beta-\mathrm{NiAl}$ and $L$ with $T$, and is expected, but measuring the same $\mathrm{Al}$ and $\mathrm{Ni}$ activities indicate $\mathrm{Ni}$ 23Al, Ni-25Al and Ni-27Al enter the same phase field, which is inconsistent with the current $\mathrm{Ni}-\mathrm{Al}$ phase diagram ${ }^{[21-25]}$. If the current $\mathrm{Ni}-\mathrm{Al}$ phase diagram is correct $\gamma^{\prime}-\mathrm{Ni}_{3} \mathrm{Al}$ remains stable up to the liquidus, and compositions either side of $\gamma^{\prime}-\mathrm{Ni}_{3} \mathrm{Al}$ (i.e., Ni$23 \mathrm{Al}$ and $\mathrm{Ni}-27 \mathrm{Al}$ ) must remain in different phase fields, separated by the composition range of $\gamma^{\prime}-\mathrm{Ni}_{3} \mathrm{Al}$ below the liquidus and by $L$ above the liquidus. These new results clearly indicate that this is not the case and the Ni-Al phase diagram needs to be revised.

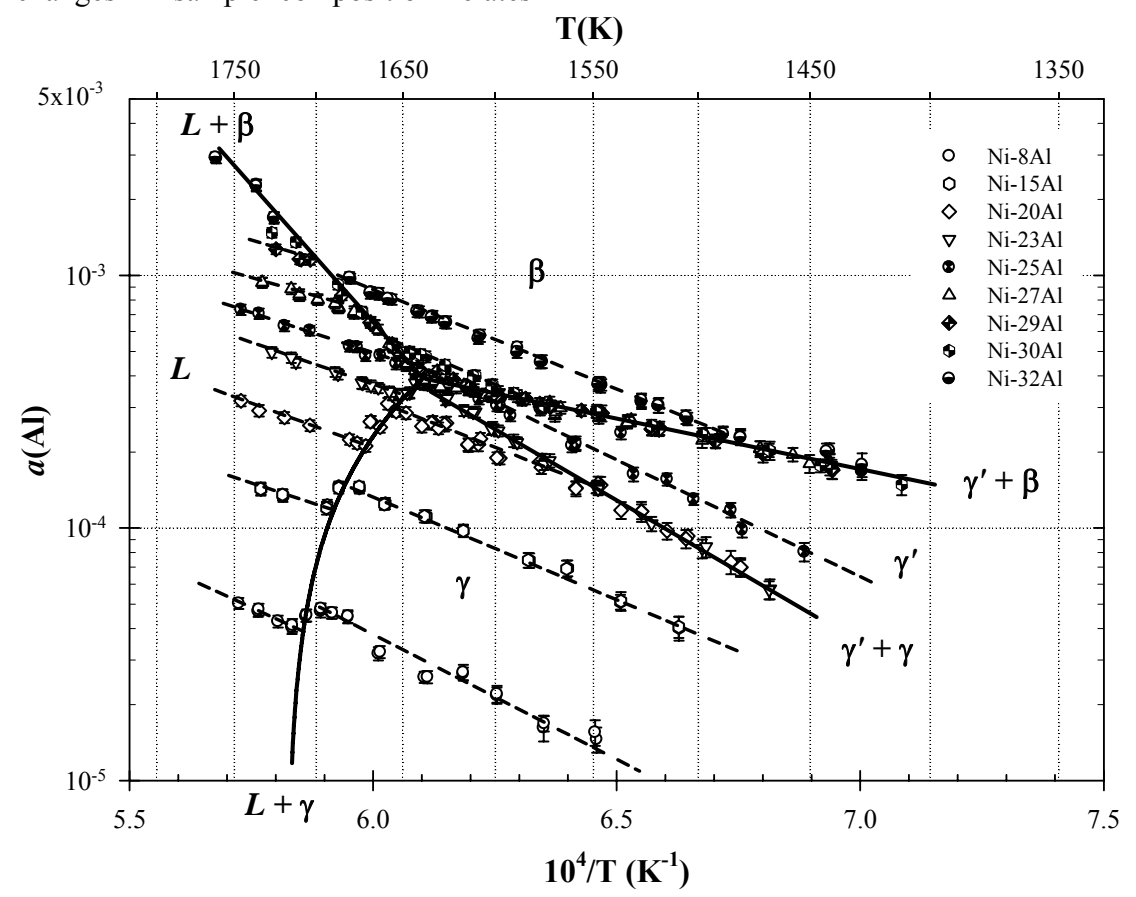

Figure 1. A plot of $\log a(\mathrm{Al})$ vs. 1/T for alloys: Ni-8Al, Ni-15Al, Ni-20Al, Ni-23Al, Ni-25Al, Ni-27Al, Ni-29Al, Ni-30Al, Ni-32Al. 


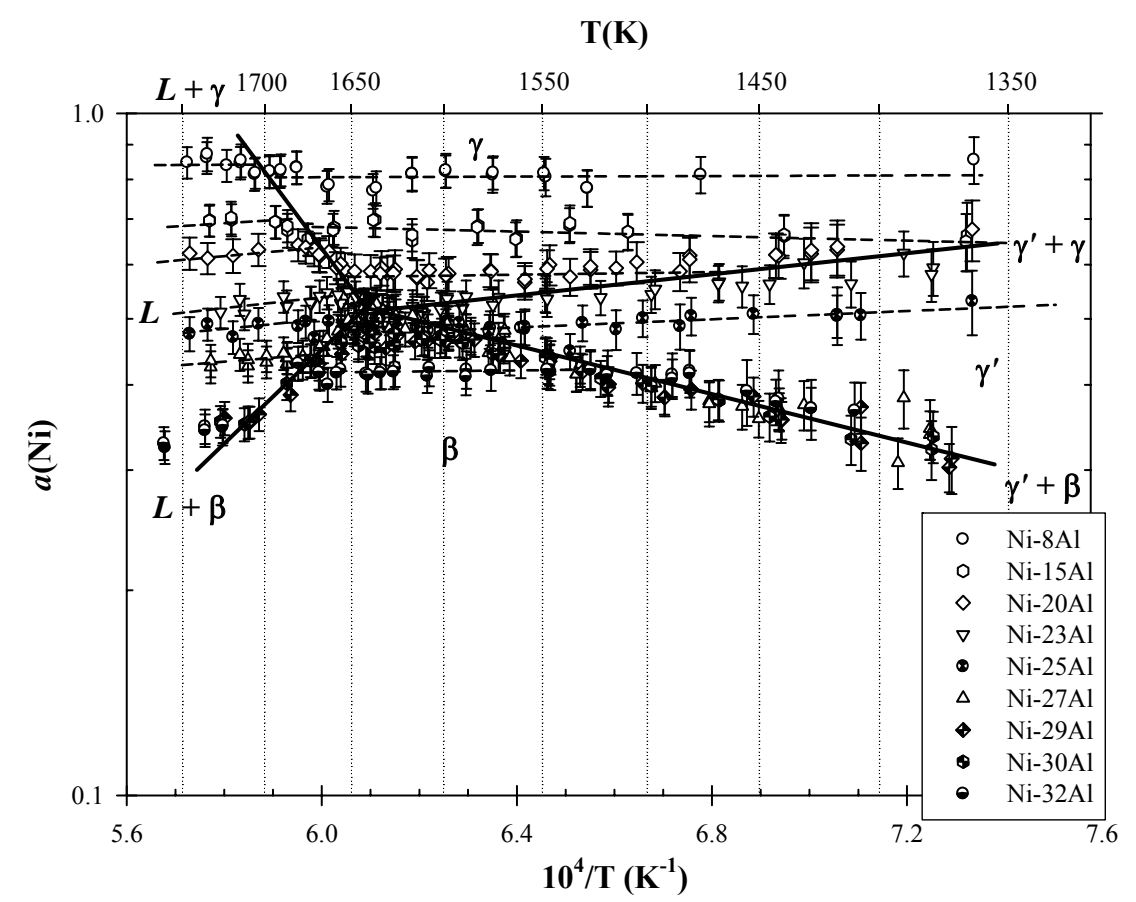

Figure 2. A plot of $\log a(\mathrm{Ni})$ vs. 1/T for alloys: Ni-8Al, Ni-15Al, Ni-20Al, Ni-23Al, Ni-25Al, Ni-27Al, Ni-29Al, Ni-30Al, Ni-32Al.

More detailed information about the phase equilibria involving $\gamma^{\prime}$ $\mathrm{Ni}_{3} \mathrm{Al}$ was obtained by placing $\mathrm{Ni}-27 \mathrm{Al}$ and $\mathrm{Ni}-23 \mathrm{Al}$ samples in adjacent effusion-cells and measuring the relative activities of $\mathrm{Ni}$ and $\mathrm{Al}$ (for $\mathrm{Ni}-27 \mathrm{Al} / \mathrm{Ni}-23 \mathrm{Al}$ ). Repeated measurements were combined and the data are plotted in Fig. 3, as relative activity versus $T$. This plot shows the relative activity of $\mathrm{Al}$ and $\mathrm{Ni}$ converge to unity over the temperature range $T=1633 \pm 1-1640$ $\pm 1 \mathrm{~K}$ where both alloys must be in the same phase field. Below $1633 \mathrm{~K}$ alloy $\mathrm{Ni}-27 \mathrm{Al}$ and $\mathrm{Ni}-23 \mathrm{Al}$ are in the $\gamma^{\prime}+\beta$ and $\gamma^{\prime}+\gamma$ univariant phase fields and the relative activities effectively represent the chemical potential difference across the composition range of $\gamma^{\prime}-\mathrm{Ni}_{3} \mathrm{Al}$, which decreases with increasing $T$.

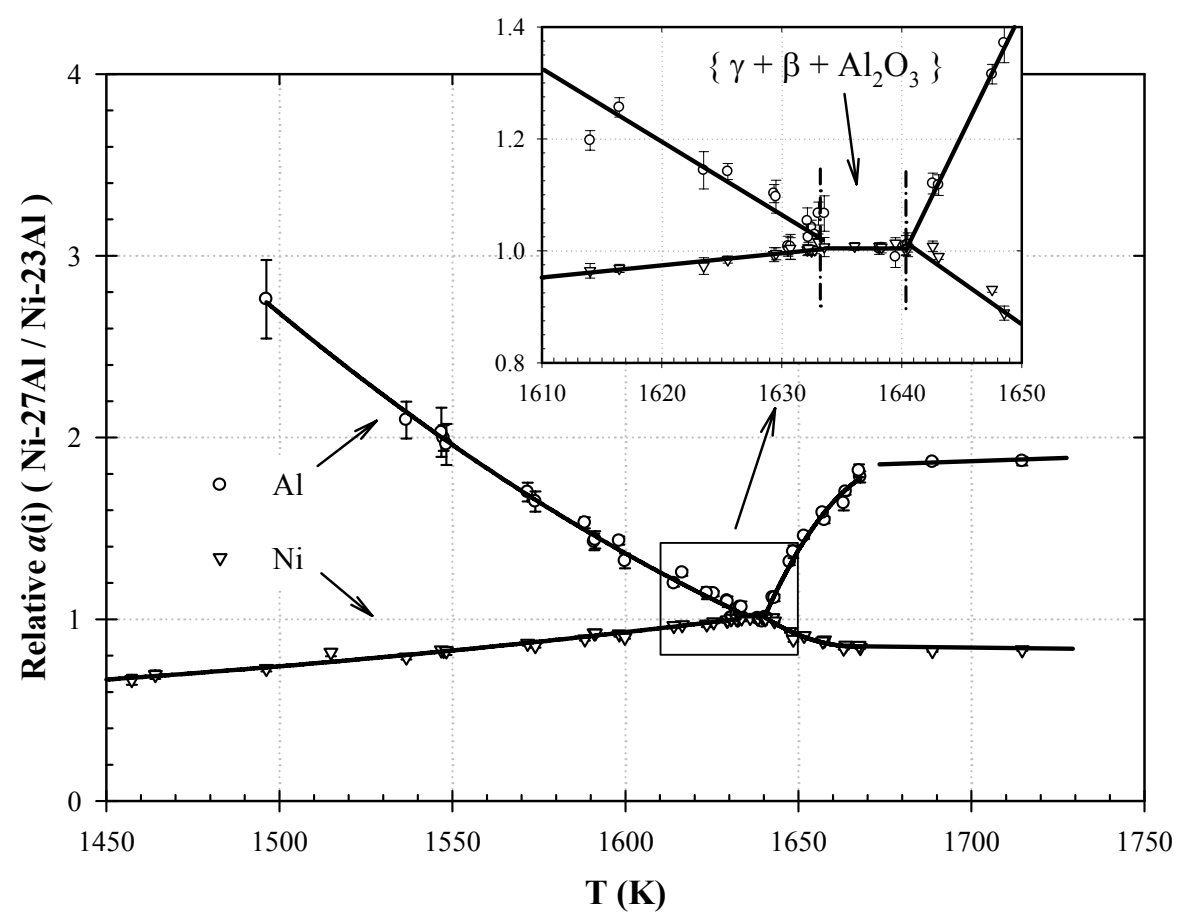

Figure 3. Relative $a(\mathrm{Al})$ and $a(\mathrm{Ni})$ for $\mathrm{Ni}-27 \mathrm{Al} / \mathrm{Ni}-23 \mathrm{Al}$ vs. T (K). 
At $T=1633 \mathrm{~K}$ this difference goes to zero (i.e., relative $a(\mathrm{Al})$ and relative $a(\mathrm{Ni})=1$ ) signifying that $\gamma^{\prime}-\mathrm{Ni}_{3} \mathrm{Al}$ is no longer stable for $T>1633 \mathrm{~K}$. Similarly above $T=1640 \mathrm{~K}$, but below the liquidus, the alloys are in the $L+\beta$ and $L+\gamma$ univariant phase fields and the relative activities represent the difference across the $L$ phase. For $T<1640 \mathrm{~K}$ the difference also goes to zero and indicating $L$ is no longer stable. According to the Gibbs phase-rule $(f=c+2-$ $p$ ), a maximum of 5 phases can coexist at an invariant point in the Ni-Al-O system. Therefore only 4 phases can be stable over the temperature range $T=1633-1640 \mathrm{~K}$ and there must be an invariant point at either end of this temperature range. As $\gamma-(\mathrm{Ni})$ and $\beta$-NiAl both remain stable up to the liquidus, $\gamma^{\prime}-\mathrm{Ni}_{3} \mathrm{Al}$ must decompose to $\gamma+\beta$ on heating via the peritectoid reaction, $\gamma+\beta$ $\left(+\mathrm{Al}_{2} \mathrm{O}_{3}\right)=\gamma^{\prime}\left(+\mathrm{Al}_{2} \mathrm{O}_{3}\right)$, at $T=1633 \pm 1 \mathrm{~K}$, which corresponds to the $\left\{\gamma^{\prime}+\gamma+\beta+\mathrm{Al}_{2} \mathrm{O}_{3}\right\}$ equilibrium. Similarly at $T=1640 \pm 1 \mathrm{~K}$ the liquid decomposes on cooling via the eutectic reaction, $L(+$ $\left.\mathrm{Al}_{2} \mathrm{O}_{3}\right)=\gamma+\beta\left(+\mathrm{Al}_{2} \mathrm{O}_{3}\right)$, which corresponds to the $\{L+\gamma+\beta+$ $\left.\mathrm{Al}_{2} \mathrm{O}_{3}\right\}$ equilibrium. Based on this argument the $\left\{\gamma+\beta+\mathrm{Al}_{2} \mathrm{O}_{3}\right\}$ equilibrium is stable over the range $T=1633-1640 \mathrm{~K}$.

Information about the broader phase equilibria in the Ni-Al-O system was obtained from the measured ratio of the ionintensities, $I_{\mathrm{Ni}} / I_{\mathrm{Al}}$, in the molecular beam from each effusion-cell with $T$. This is effectively the ratio, $a(\mathrm{Ni}) / a(\mathrm{Al})$, in each alloy and is independent of results shown in Figs. 1, 2 and 3. Figure 4 shows the results from all samples on a plot of the natural logarithm of $I_{\mathrm{Ni}} / I_{\mathrm{Al}}$ versus $1 / T$. The same procedure, discussed above, was used to identify the behavior of each sample as it traversed the univariant and bivariant phase fields. This data is more suited to identifying phase boundaries and invariant transformations. For example, point $\mathrm{A}$ in Fig. 4 represents the solidus $\gamma+\mathrm{Al}_{2} \mathrm{O}_{3} / L+\gamma+\mathrm{Al}_{2} \mathrm{O}_{3}(T=1675 \pm 5 \mathrm{~K})$ for the Ni$15 \mathrm{Al}$ sample, while point $\mathrm{B}$ represents the $\gamma$-(Ni) solvus $\gamma+\gamma^{\prime}+$ $\mathrm{Al}_{2} \mathrm{O}_{3} / \gamma+\mathrm{Al}_{2} \mathrm{O}_{3}(T=1541 \pm 8 \mathrm{~K})$ for Ni-20Al. An invariant transformation is identified by the point of intersection of 2 univariant phase fields. All the phase boundary data obtained in this study (from Fig. 3 and 4) are summarized in Table 3.

Table 3. Phase Boundaries and Invariant Reactions

\begin{tabular}{|c|c|c|}
\hline Alloy & Phase Boundary & $T(\mathrm{~K})$ \\
\hline \multirow[t]{2}{*}{$\mathrm{Ni}-8 \mathrm{Al}$} & $\gamma+\mathrm{Al}_{2} \mathrm{O}_{3} / L+\gamma+\mathrm{Al}_{2} \mathrm{O}_{3}$ & $1697 \pm 4$ \\
\hline & $L+\gamma+\mathrm{Al}_{2} \mathrm{O}_{3} / L+\mathrm{Al}_{2} \mathrm{O}_{3}$ & $1715 \pm 3$ \\
\hline \multirow{2}{*}{$\mathrm{Ni}-15 \mathrm{Al}$} & $\gamma+\mathrm{Al}_{2} \mathrm{O}_{3} / L+\gamma+\mathrm{Al}_{2} \mathrm{O}_{3}$ & $1675 \pm 5$ \\
\hline & $L+\gamma+\mathrm{Al}_{2} \mathrm{O}_{3} / L+\mathrm{Al}_{2} \mathrm{O}_{3}$ & $1695 \pm 5$ \\
\hline \multirow{3}{*}{$\mathrm{Ni}-20 \mathrm{Al}$} & $\gamma+\gamma^{\prime}+\mathrm{Al}_{2} \mathrm{O}_{3} / \gamma+\mathrm{Al}_{2} \mathrm{O}_{3}$ & $1541 \pm 8$ \\
\hline & $\gamma+\mathrm{Al}_{2} \mathrm{O}_{3} / L+\gamma+\mathrm{Al}_{2} \mathrm{O}_{3}$ & $1651 \pm 4$ \\
\hline & $L+\gamma+\mathrm{Al}_{2} \mathrm{O}_{3} / L+\mathrm{Al}_{2} \mathrm{O}_{3}$ & $1674 \pm 3$ \\
\hline \multirow{3}{*}{$\mathrm{Ni}-23 \mathrm{Al}$} & $\gamma+\gamma^{\prime}+\mathrm{Al}_{2} \mathrm{O}_{3} / \gamma+\beta+\mathrm{Al}_{2} \mathrm{O}_{3}$ & $1633 \pm 1$ \\
\hline & $\gamma+\beta+\mathrm{Al}_{2} \mathrm{O}_{3} / L+\gamma+\mathrm{Al}_{2} \mathrm{O}_{3}$ & $1640 \pm 1$ \\
\hline & $L+\gamma+\mathrm{Al}_{2} \mathrm{O}_{3} / L+\mathrm{Al}_{2} \mathrm{O}_{3}$ & $1649 \pm 1$ \\
\hline \multirow{4}{*}{$\mathrm{Ni}-25 \mathrm{Al}$} & $\gamma^{\prime}+\mathrm{Al}_{2} \mathrm{O}_{3} / \gamma^{\prime}+\beta+\mathrm{Al}_{2} \mathrm{O}_{3}$ & $1614 \pm 6$ \\
\hline & $\gamma^{\prime}+\beta+\mathrm{Al}_{2} \mathrm{O}_{3} / \gamma+\beta+\mathrm{Al}_{2} \mathrm{O}_{3}^{\dagger}$ & $1633 \pm 1$ \\
\hline & $\gamma+\beta+\mathrm{Al}_{2} \mathrm{O}_{3} / L+\beta+\mathrm{Al}_{2} \mathrm{O}_{3}$ & $1639 \pm 2$ \\
\hline & $L+\beta+\mathrm{Al}_{2} \mathrm{O}_{3} / L+\mathrm{Al}_{2} \mathrm{O}_{3}$ & $1646 \pm 1$ \\
\hline \multirow{3}{*}{$\mathrm{Ni}-27 \mathrm{Al}$} & $\gamma^{\prime}+\beta+\mathrm{Al}_{2} \mathrm{O}_{3} / \gamma+\beta+\mathrm{Al}_{2} \mathrm{O}_{3}$ & $1633 \pm 1$ \\
\hline & $\gamma+\beta+\mathrm{Al}_{2} \mathrm{O}_{3} / L+\beta+\mathrm{Al}_{2} \mathrm{O}_{3}$ & $1640 \pm 1$ \\
\hline & $L+\beta+\mathrm{Al}_{2} \mathrm{O}_{3} / L+\mathrm{Al}_{2} \mathrm{O}_{3}$ & $1672 \pm 1$ \\
\hline \multirow{3}{*}{$\mathrm{Ni}-29 \mathrm{Al}$} & $\gamma^{\prime}+\beta+\mathrm{Al}_{2} \mathrm{O}_{3} / \beta+\mathrm{Al}_{2} \mathrm{O}_{3}$ & $1605 \pm 5$ \\
\hline & $\beta+\mathrm{Al}_{2} \mathrm{O}_{3} / L+\beta+\mathrm{Al}_{2} \mathrm{O}_{3}$ & $1642 \pm 3$ \\
\hline & $L+\beta+\mathrm{Al}_{2} \mathrm{O}_{3} / L+\mathrm{Al}_{2} \mathrm{O}_{3}$ & $1704 \pm 2$ \\
\hline \multirow{3}{*}{$\mathrm{Ni}-30 \mathrm{Al}$} & $\gamma^{\prime}+\beta+\mathrm{Al}_{2} \mathrm{O}_{3} / \beta+\mathrm{Al}_{2} \mathrm{O}_{3}$ & $1585 \pm 8$ \\
\hline & $\beta+\mathrm{Al}_{2} \mathrm{O}_{3} / L+\beta+\mathrm{Al}_{2} \mathrm{O}_{3}$ & $1657 \pm 2$ \\
\hline & $L+\beta+\mathrm{Al}_{2} \mathrm{O}_{3} / L+\mathrm{Al}_{2} \mathrm{O}_{3}$ & $1714 \pm 5$ \\
\hline \multirow{2}{*}{$\mathrm{Ni}-32 \mathrm{Al}$} & $\gamma^{\prime}+\beta+\mathrm{Al}_{2} \mathrm{O}_{3} / \beta+\mathrm{Al}_{2} \mathrm{O}_{3}$ & $1485 \pm 4$ \\
\hline & $\beta+\mathrm{Al}_{2} \mathrm{O}_{3} / L+\beta+\mathrm{Al}_{2} \mathrm{O}_{3}$ & $1681 \pm 4$ \\
\hline
\end{tabular}

$\dagger$ It was impossible to determine the $\gamma^{\prime}+\beta+\mathrm{Al}_{2} \mathrm{O}_{3} / \gamma+\beta+\mathrm{Al}_{2} \mathrm{O}_{3}$ transformation temperature from these data

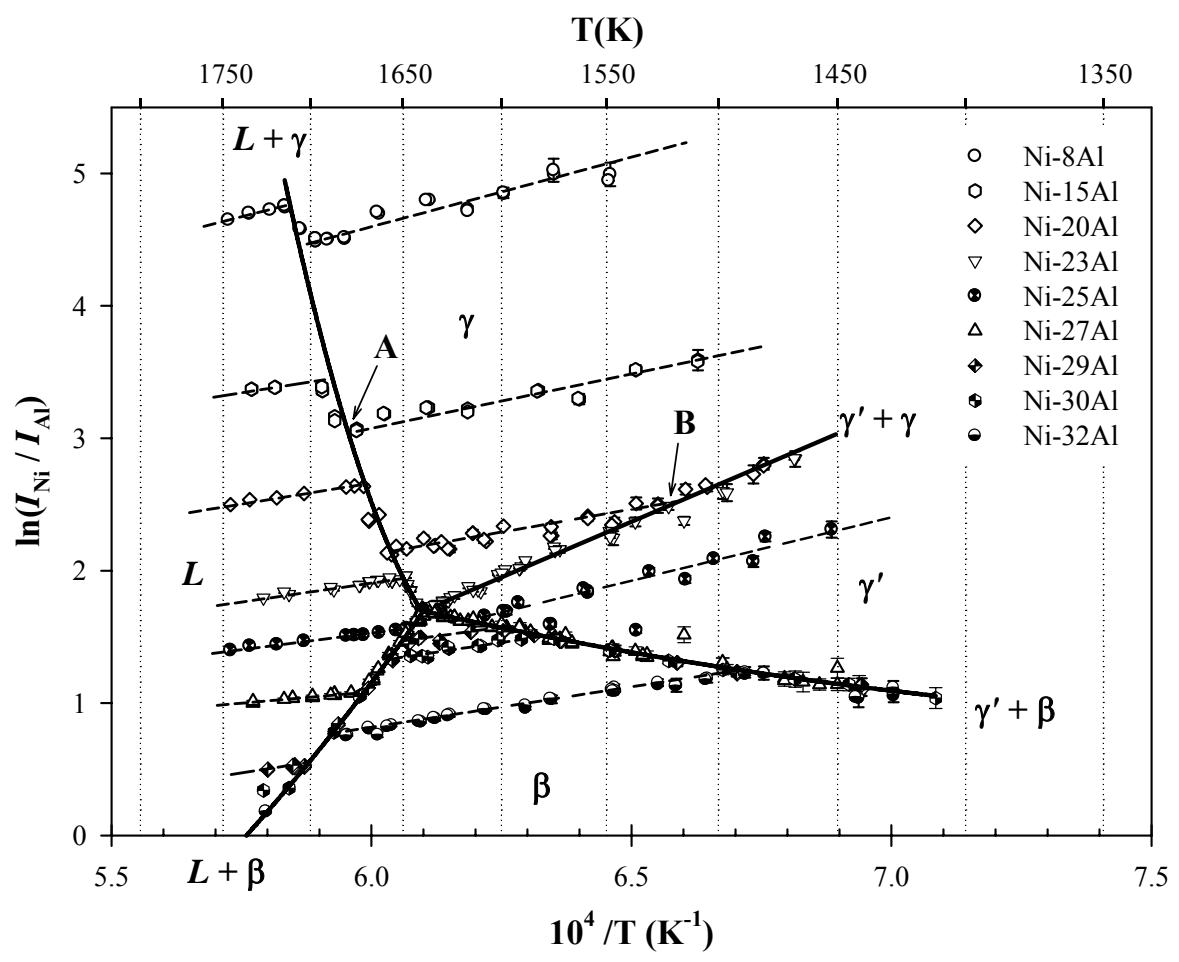

Figure 4. Measured $\ln \left(I_{\mathrm{Ni}} / I_{\mathrm{Al}}\right)$ vs. $1 / \mathrm{T}$ for: Ni-8Al, Ni-15Al, Ni-20Al, Ni-23Al, Ni-25Al, Ni-27Al, Ni-29Al, Ni-30Al, Ni-32Al. 


\section{Discussion}

The measured reaction enthalpies for $\left\{\mathrm{Al}(\mathrm{l})+\mathrm{Al}_{2} \mathrm{O}_{3}\right\}$ listed in column 2 of table 2 are significant with potentially wide ranging ramifications. While the vaporization behavior of $\left\{\mathrm{Al}(\mathrm{l})+\mathrm{Al}_{2} \mathrm{O}_{3}\right\}$ has no influence on the eutectic and perperitectoid transformations involving $\gamma^{\prime}-\mathrm{Ni}_{3} \mathrm{Al}$ observed in this study, it raises some questions about the accepted thermodynamic properties of $\mathrm{Al}(\mathrm{s}, 1, \mathrm{~g})$, the value of $p^{\circ}(\mathrm{Al})$ and thus previously measured $a(\mathrm{Al})$ data and published thermodynamic description of systems that contain Al. Therefore a brief discussion of these new results and review of the previously published thermodynamic data for $\mathrm{Al}$ is provided. The reaction enthalpies listed in table 2 were determined during repeated measurements of the $\mathrm{S}_{\mathrm{Au}} / \mathrm{S}_{\mathrm{Al}}$ and $\mathrm{S}_{\mathrm{Au}} / \mathrm{S}_{\mathrm{A} 12 \mathrm{O}}$ calibration terms that relate $\mathrm{Au}(\mathrm{s}, 1)$ or $p^{\circ}(\mathrm{Au})$, to $\left\{\mathrm{Al}(\mathrm{l})+\mathrm{Al}_{2} \mathrm{O}_{3}(\mathrm{~s})\right\}$ or $p^{\circ}(\mathrm{Al})$ and $p^{\circ}\left(\mathrm{Al}_{2} \mathrm{O}\right)$. In these experiments the $2^{\text {nd }}$ and $3^{\text {rd }}$ law values for the enthalpy of sublimation of $\mathrm{Au}(\mathrm{s})$ were measured in the ranges $363.0 \pm 3.0 \mathrm{kJmol}^{-1}$ and $367.0 \pm 1.5 \mathrm{kJmol}^{-1}$, respectively. Similarly the $2^{\text {nd }}$ law enthalpy of sublimation of $\mathrm{Al}(\mathrm{s})$ was repeatedly measured in the range $341.0 \pm 2.2 \mathrm{kJmol}^{-1}$. (The Gibbs free energy functions $\left(G^{\mathrm{o}}(T)-H^{\mathrm{o}}(298) / T\right)$ for the pure substances used in these calculations came from references 46 and 47.) This differs significantly form the currently recommended value of $330.0 \pm 3.0$ $\mathrm{kJmol}^{-1}[47,48]$ but given that the accepted sublimation of $\mathrm{Au}(\mathrm{s})$ was reproduced in the same experiments there is no compelling reason question the validity of these new results. While some issues were investigated by the author ${ }^{[51,52]}$ the underlying fact is that $\mathrm{Al}(\mathrm{l})$ is highly reactive and to date the most suitable container has not been widely used, and to make matters worse different containers have been used for vaporization and calorimetric studies. A review of the literature reveals that graphite, $\mathrm{BeO}$, $\mathrm{TaC}, \mathrm{Ta}_{5} \mathrm{Si}, \mathrm{ZrC}, \mathrm{BN}, \mathrm{TiB}_{2}, \mathrm{Al}_{2} \mathrm{O}_{3}$ and $\mathrm{ZrO}_{2}$ have all being used to contain $\mathrm{Al}(\mathrm{l})$, with varying degrees of success, in melting point, calorimetry and vaporization studies. Because $\mathrm{Al}_{2} \mathrm{O}_{3}$ is such a stable compound it is impractical to consider $\mathrm{Al}$ independently of $\mathrm{O}$, however, the Al-O phase diagram ${ }^{[33]}$ indicates $\mathrm{Al}_{2} \mathrm{O}_{3}$ is in equilibrium with $\mathrm{Al}(\mathrm{l})$ and the $\mathrm{O}$ saturation limit is less then 0.1 at $\% \mathrm{O}$ at temperatures above $2000 \mathrm{~K}$. In addition, $\mathrm{Al}_{2} \mathrm{O}_{3}$ exhibits slow diffusion kinetics for both $\mathrm{O}$ and Al. Accordingly $\mathrm{Al}_{2} \mathrm{O}_{3}$ is the perfect container for $\mathrm{Al}(\mathrm{l})$ and the univariant equilibrium $\left\{\mathrm{Al}(\mathrm{l})+\mathrm{Al}_{2} \mathrm{O}_{3}\right\}$ unambiguously defines $p^{\circ}(\mathrm{Al})$, $p^{\circ}\left(\mathrm{Al}_{2} \mathrm{O}\right)$ and $p^{*}(\mathrm{O})$ and provides an excellent experimental reference state for $\mathrm{Al}, \mathrm{Al}_{2} \mathrm{O}, \mathrm{O}$ and $\mathrm{Al}_{2} \mathrm{O}_{3}{ }^{[43]}$.

Unfortunately to date there have been no reliable studies reporting the vaporization behavior of $\left\{\mathrm{Al}(\mathrm{l})+\mathrm{Al}_{2} \mathrm{O}_{3}\right\}$. As a result all the studies cited in the thermodynamic compilations (JANAF, TPIS, CODATA, etc.) as the basis of the recommended $\Delta \mathrm{H}_{\text {sub }} \mathrm{Al}(298)$

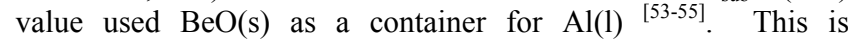
surprising because both Brewer et al. [54] and Potter et al. [53] clearly state that $\mathrm{Al}(\mathrm{l})$ reacts with the $\mathrm{BeO}$ (s) to form unidentified $\mathrm{AlBe}_{\mathrm{x}} \mathrm{O}_{\mathrm{y}}$ compounds together with the dissolution of $2 \sim 5 \mathrm{at} \% \mathrm{Be}$ in $\mathrm{Al}(\mathrm{l})$. If these observations are correct the reported vaporization behavior cannot be assigned to pure $\mathrm{Al}(1)$ and indeed this is the likely cause for the discrepancy seen in table 2 . Further, reference [53] is a progress report for a wide ranging project that only contains a brief summary of the vaporization of $\mathrm{Al}(\mathrm{l})$ consisting of the $2^{\text {nd }}$ and $3^{\text {rd }}$ law values for $\Delta \mathrm{H}_{\text {sub }} \mathrm{Al}(298)$ and it turns out that the measured $p(\mathrm{Al})$ versus $T$ data was never actually published ${ }^{[56]}$. The critical calorimetric study of $\mathrm{Al}(1)$ by McDonald [57] used to determine the heat capacity and Gibbs free energy function of $\mathrm{Al}(\mathrm{l})$ used both $\mathrm{BN}$ and $\mathrm{TiB}_{2}$ to contain $\mathrm{Al}(\mathrm{l})$. $\mathrm{BN}$ is unsuitable because $\mathrm{AlN}$ and $\mathrm{AlB}_{2}$ need to form before $\mathrm{Al}(\mathrm{l})$ is stable but neither compound provides a suitable diffusion barrier to stop the reaction of $\mathrm{Al}$ with the $\mathrm{BN}$ container. After $\mathrm{Al}_{2} \mathrm{O}_{3}, \mathrm{TiB}_{2}$ is probably the best container for $\mathrm{Al}(\mathrm{l})$ because the $\left\{\mathrm{Al}(\mathrm{l})+\mathrm{TiB}_{2}\right\}$ and $\left\{\mathrm{Al}(\mathrm{l})+\mathrm{TiAl}_{3}+\mathrm{TiB}_{2}\right\}$ equilibria exist, in fact $\mathrm{TiB}_{2}$ has a long history as a grain refiner for Al-based alloys. However, at high $T$ significant dissolution of $\mathrm{Ti}$ and $\mathrm{B}$ in $\mathrm{Al}(\mathrm{l})$ occurs and it is uncertain if a univariant equilibrium exists. It is unclear why calorimetric / heat capacity measurements of $\mathrm{Al}(1)$ were never made in $\mathrm{Al}_{2} \mathrm{O}_{3}$ containers. Given that $\mathrm{Al}$ is such an important component in a wide range of alloys currently used in many industrial applications there is an urgent need to re-measure the heat capacity and vaporization behavior of $\mathrm{Al}(1)$ to elucidate the inconsistency in the accepted thermodynamic data. Ideally heat capacity and vaporization measurements of $\mathrm{Al}(\mathrm{l})$ need to be made in consistent containers (i.e., $\mathrm{Al}_{2} \mathrm{O}_{3}, \mathrm{TiB}_{2}$ and possibly AlN).

On returning to the eutectic and perperitectoid reactions observed in this study, it is important to recognize the system considered in this study is essentially the same as in all previous studies ${ }^{[1-25]}$. While the system was identified as Ni-Al-O in this study, changing the description of the system cannot influence the actual measurements. The different behavior reported here is a consequence of the isothermal conditions, obtaining equilibrium at each $T$ and a significant improvement in experimental capability provided by the multi-cell KEMS technique. The limited temperature range where $\left\{\gamma+\beta+\mathrm{Al}_{2} \mathrm{O}_{3}\right\}$ is stable, the similar composition of the $L$ in the eutectic and $\gamma^{\prime}-\mathrm{Ni}_{3} \mathrm{Al}$ (as shown in Fig. 5) together with fast reaction kinetics make the details of this behavior very difficult to observe with more conventional non-isothermal techniques. The ability to compare the partial thermodynamic properties from different samples at temperature provides direct information about differences in the phase equilibria and provides an excellent tool for investigating complex phase transformations under equilibrium conditions. This capability needs to be applied to a wide range of technically important alloy and ceramic systems.

Combining the data listed in tables 1 and 3 provide $24\left(X_{\mathrm{Al}}, T\right)$ points that correspond to various phase boundaries, which were used to construct the section of the "Ni-Al" phase diagram shown in Fig. 5. Given that measurements made in the Ni-Al-O system have been routinely applied to the $\mathrm{Ni}-\mathrm{Al}$ system, for the purpose of this discussion the current results are also presented in this way to allow a direct comparison with previous studies. To avoid confusion, however, Fig. 5 is a projection of the alloy phase boundaries observed in the Ni-Al-O system on to the Ni-Al binary edge of the ternary system, where the alloy phases are saturated with $\mathrm{O}$ and in equilibrium with $\mathrm{Al}_{2} \mathrm{O}_{3}$. For the purpose of this comparison the proposed phase equilibrium (the thick solid / dashed lines and data points) has been superimposed on the current $\mathrm{Ni}-\mathrm{Al}$ phase diagram (thinner solid grey lines) from the assessment of Huang and Chang ${ }^{[24]}$. There is just enough data to define the shape of the liquidus, solidus $(\gamma-(\mathrm{Ni}), \beta-\mathrm{NiAl}$ and $\gamma-(\mathrm{Ni})$ $+\beta$-NiAl) and $\beta$-NiAl solvus boundaries shown in Fig. 5 , but the placement of the $\gamma-(\mathrm{Ni})$ solvus and $\gamma^{\prime}-\mathrm{Ni}_{3} \mathrm{Al}$ phase boundaries is pure conjecture based on the currently accepted behavior. The critical finding of this study is that $\gamma^{\prime}-\mathrm{Ni}_{3} \mathrm{Al}$ forms via the peritectiod reaction $\gamma+\beta\left(+\mathrm{Al}_{2} \mathrm{O}_{3}\right)=\gamma^{\prime}\left(+\mathrm{Al}_{2} \mathrm{O}_{3}\right)$, at $T=1633 \pm 1$ $\mathrm{K}$, below the liquidus and $\gamma^{\prime}-\mathrm{Ni}_{3} \mathrm{Al}$ is not involved in either a eutectic or peritectic reaction as currently accepted. 


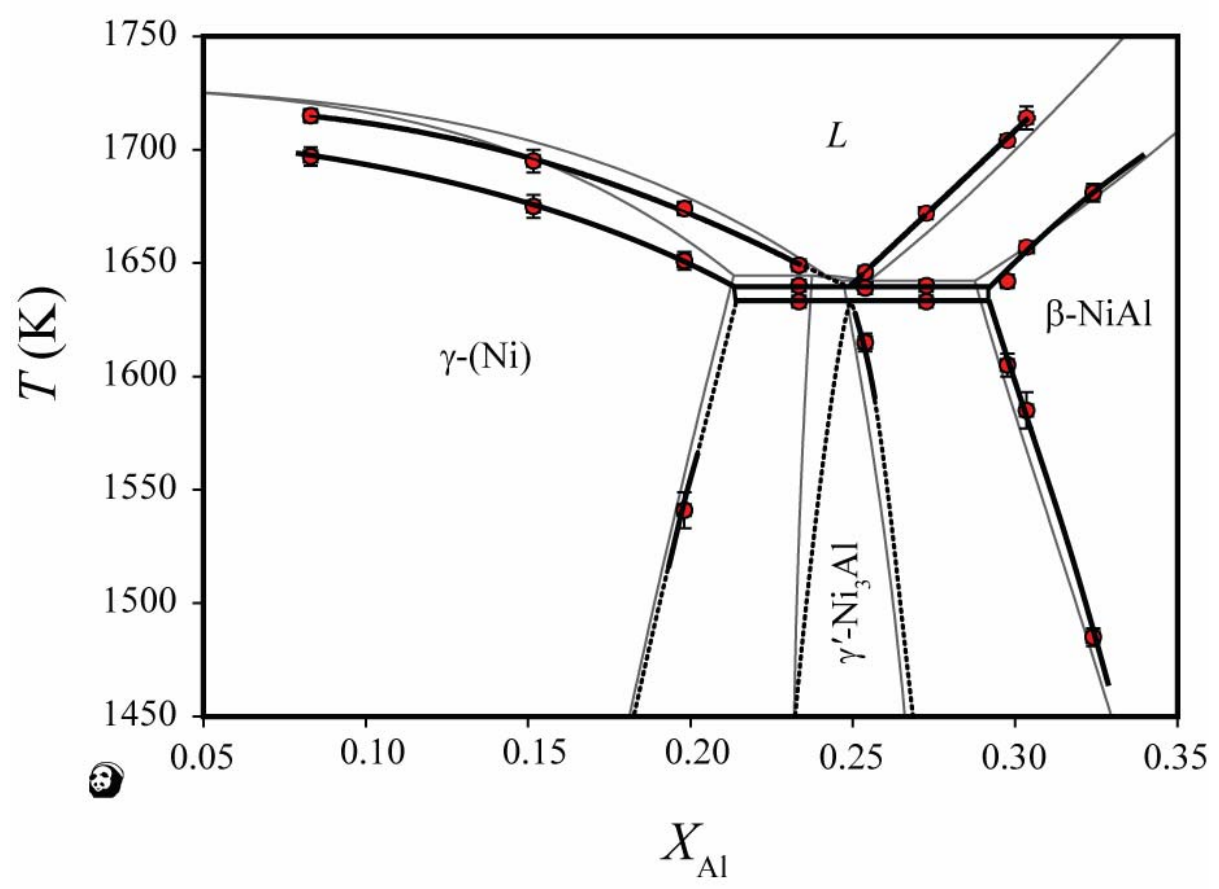

Figure 5. The projection of the alloy phase boundaries within the Ni-Al-O system, in equilibrium with $\mathrm{Al}_{2} \mathrm{O}_{3}$ and saturated with $\mathrm{O}$, on to the Ni-Al binary edge. The phase boundary points in this figure were taken from the data listed in Tables 1 and 3 . These new data are superimposed (shown as thick solid / dashed lines) over the current Ni-Al phase diagram (thinner solid grey line) from the assessment of Huang and Chang ${ }^{[24]}$.

Above the peritectoid, over the temperature range $T=1633-$ $1640 \mathrm{~K}, \gamma-(\mathrm{Ni})$ and $\beta-\mathrm{NiAl}$ are in equilibrium and at $T=1640 \pm 1$ $\mathrm{K}$ there is a eutectic reaction, $L\left(+\mathrm{Al}_{2} \mathrm{O}_{3}\right)=\gamma+\beta\left(+\mathrm{Al}_{2} \mathrm{O}_{3}\right)$. An estimate of the liquid composition at the eutectic, $24.8 \pm 0.2$ at $\%$ $\mathrm{Al}$, was obtained by extrapolating the measured liquidus on either side of the eutectic down to the eutectic temperature, $T=1640 \mathrm{~K}$. The composition of $\gamma^{\prime}-\mathrm{Ni}_{3} \mathrm{Al}$ at the peritectiod reaction cannot be determined form these data but it is clearly to the Ni-rich side of $\mathrm{Ni}-25 \mathrm{Al}$ composition and close to the composition of $L$ in the eutectic. Apart from the solidification behavior of $\gamma^{\prime}-\mathrm{Ni}_{3} \mathrm{Al}$ there is good agreement in the $\gamma$ - $(\mathrm{Ni})$ solvus, $\beta$-NiAl solvus, liquidus, $\beta$ $\mathrm{NiAl}$ solidus and Al-rich $\gamma^{\prime}-\mathrm{Ni}_{3} \mathrm{Al}$ phase boundary between the results reported in this study and Huang's assessment. However, there is a significant difference in the position of the $\gamma$-(Ni) solidus and nature of this discrepancy needs further investigation.

In view of the fact that these results represent such a large departure from the accepted phase equilibrium in the $\mathrm{Ni}-\mathrm{Al}$ system, the reproducibility of this behavior was checked with three independent measurements (absolute activities Fig. 1 and 2, relative activities Fig. 3 and ion-intensity ratios Fig. 4). All three sets of measurements showed consistent behavior across the thirteen experiments. It would be ideal if the $\left\{\gamma+\beta+\mathrm{Al}_{2} \mathrm{O}_{3}\right\}$ phase field was confirmed directly by quenching in the high temperature microstructure and observing it by optical and electron microscopy. Unfortunately this experiment cannot be conducted with the multi-cell furnace because it is under a high vacuum and high cooling rates are impossible. A cursory review of the relevant literature reveals that $\gamma+\beta$ eutectic structures have in fact been routinely observed in the $\mathrm{Ni}-\mathrm{Al}$ system and the factors affecting their formation, during directional solidification, have been studied in detail ${ }^{[12,14,16]}$. These studies were founded on view that the current $\mathrm{Ni}-\mathrm{Al}$ phase diagrams is correct (i.e., $\gamma^{\prime}$ $\mathrm{Ni}_{3} \mathrm{Al}$ is stable up to the liquidus and is involved in both $L+\gamma=\gamma^{\prime}$ and $L=\beta+\gamma^{\prime}$ reactions) and the aim was to understand how the "metastable" $\gamma+\beta$ eutectic structure formed as a function of directional solidification conditions. However, in the light provided by these new results and the proposed phase equilibrium in the $\mathrm{Ni}-\mathrm{Al}$ system it is interesting to reconsider the discussion surrounding the stability and formation of $\gamma+\beta$ eutectic structures.

Lee and Verhoeven ${ }^{[12-15]}$ used the Bridgman technique with a thermal gradient of $20-40 \mathrm{~K} / \mathrm{cm}$ in the liquid, the alloy samples (with $\mathrm{Al}$ content $23-27$ at $\% \mathrm{Al}$ ) were placed in an $\mathrm{Al}_{2} \mathrm{O}_{3}$ tube and a sample feed rate of $0.8-61 \mu \mathrm{m} / \mathrm{s}$ was used. A range of quenching methods (in order of increasing cooling rate: air, water, ice-water and molten Ga-In) were employed in an attempt to freeze in the steady-state solidification structures. In addition to the $\gamma+\beta$ eutectic these studies also revealed unusually wide lamella spacing in $\gamma^{\prime}+\beta$ structures, $\gamma^{\prime} / \gamma^{\prime}$ interfaces ${ }^{[13]}$ and two cellular structures of $\gamma^{\prime}+\beta$ and $\gamma+\gamma^{\prime}+\beta$ (the latter contradicts the Gibbs phase rule), all of which the authors felt could not be adequately explained. (While their initial publication ${ }^{[12]}$ is widely cited as a critical study proving the accepted Ni-Al phase equilibrium in the development of the thermodynamic descriptions ${ }^{[22-24]}$ all subsequent publications reporting unusual microstructures were and are still inexplicably ignored.) From 
this author's perspective, the basic finding was directional solidification conditions did not influence which eutectic formed, rather the quenching method determined if a $\gamma+\beta$ or $\gamma^{\prime}+\beta$ was observed. This conclusion comes from the idea that reactions occurring at temperature during the steady state directional solidification are independent of any subsequent reactions occurring during the quenching and the probability of quenchingin the steady-state solidification structure increases as the cooling rate increases. The $\gamma+\beta$ eutectic structure was observed in samples that were cooled at the highest rates (i.e., a molten Ga-In bath and sometimes iced-water quench) while the various $\gamma^{\prime}+\beta$ and $\gamma^{\prime}+\gamma$ structures were only observed in samples cooled more slowly. This indicates the $\gamma+\beta$ eutectic structure must be the stable steady-state solidification structure and not a metastable structure as has been suggested. The formation of a $\gamma+\beta$ eutectic under steady-state solidification conditions agrees with the new Ni-Al phase diagram proposed in this study. The most compelling evidence of this is found in figure 2 of reference [14] which presents a quenched high-temperature microstructure that clearly shows: the $L=\gamma+\beta$ eutectic at the liquid / solid interface; the $\gamma+\beta$ eutectic structure over a limited temperature range; the $\gamma$ $+\beta=\gamma^{\prime}$ peritectiod with $\gamma^{\prime}$ nucleating at $\gamma / \beta$ interfaces and growth into lamella of $\gamma$ and $\beta$ as the sample continues to cool (producing metastable $\gamma+\gamma^{\prime}+\beta$ structures).

In a similar study, Hunziker and Kurz ${ }^{[16]}$ investigated the factors influencing the formation of $\gamma+\beta$ eutectic structures over the composition range $11-30$ at.\%Al. They used a laser surface resolidification technique on samples at room temperature and $1273 \mathrm{~K}$ over a wide range of velocities $\left(5 \times 10^{-4}-0.5 \mathrm{~ms}^{-1}\right)$. In all cases the un-melted bulk of these samples provide a large enough heat-sink to give a high cooling rate (or auto-quenching) which successfully preserved the steady-state solidification structure. Only the $\gamma+\beta$ eutectic alone and together with prior- $\beta$ or prior- $\gamma$ were observed. The absence of primary $\gamma^{\prime}-\mathrm{Ni}_{3} \mathrm{Al}$ indicates it is not stable up to the liquidus and it was suggested that $\gamma^{\prime}$ form by a nucleation and growth process (shown schematically in figure 9 in reference [16]) that is effectively a $\gamma+\beta=\gamma^{\prime}$ peritectiod reaction. This behavior agrees with Lee and Verhoeven and the results presented in this publication. Further independent conformation of this phase equilibrium is also found in the measurements of the temperature dependence of the long-range order parameter of $\gamma^{\prime}$ $\mathrm{Ni}_{3} \mathrm{Al}$ made by Bremer et al. [7]. Their study used high temperature $\gamma$-ray diffraction to measure the Bragg scattering intensity of the fundamental (200) and superlattice (100) reflection to calculate the long range order in $\mathrm{Ni}-24 \mathrm{Al}$ and $\mathrm{Ni}$ $22 \mathrm{Al}$ alloys. The results clearly show $\gamma^{\prime}-\mathrm{Ni}_{3} \mathrm{Al}$ remains highly ordered up to about $T=1590 \mathrm{~K}$ but starts to disorder above $T=$ $1610 \mathrm{~K}$ and is completely disordered below the solidus. Bremer et al. suggest an order-disorder transition but these results could also indicate the $\gamma+\beta=\gamma^{\prime}$ peritectoid reaction identified in the current study.

If all the reported invariant transformation behavior is viewed objectively with the possibility of choosing between the current $\mathrm{Ni}-\mathrm{Al}$ phase diagram and the behavior shown in Fig. 5 it is clear that all the previously reported data are completely consistent with the new behavior reported in this study. However, if the phase equilibrium reported in this study is used all of these prior observations can be explained in a straightforward manner.

\section{Conclusion}

The activities of $\mathrm{Al}$ and $\mathrm{Ni}$ were measured with the multi-cell KEMS technique over the composition range $8-32$ at.\%Al and temperature range and $T=1400-1750 \mathrm{~K}$ to better understand the equilibrium solidification behavior of $\gamma^{\prime}-\mathrm{Ni}_{3} \mathrm{Al}$ containing alloys in the Ni-Al-O system. The data clearly showed the univariant phase fields: $\left\{\gamma^{\prime}+\gamma+\mathrm{Al}_{2} \mathrm{O}_{3}\right\},\left\{\gamma^{\prime}+\beta+\mathrm{Al}_{2} \mathrm{O}_{3}\right\},\left\{\gamma+L+\mathrm{Al}_{2} \mathrm{O}_{3}\right\}$ and $\left\{\beta+L+\mathrm{Al}_{2} \mathrm{O}_{3}\right\}$, converged over the temperature range $T=$ $1633 \pm 1-1640 \pm 1 \mathrm{~K}$ where the same $a(\mathrm{Al})$ and $a(\mathrm{Ni})$ exist in the composition range $23-27$ at.\%Al. This behavior reveals that $\gamma^{\prime}-\mathrm{Ni}_{3} \mathrm{Al}$ is not involved in either a eutectic or peritectic but forms via the peritectiod reaction $\gamma+\beta\left(+\mathrm{Al}_{2} \mathrm{O}_{3}\right)=\gamma^{\prime}\left(+\mathrm{Al}_{2} \mathrm{O}_{3}\right)$, at $T=$ $1633 \pm 1 \mathrm{~K}$. The $\left\{\gamma+\beta+\mathrm{Al}_{2} \mathrm{O}_{3}\right\}$ phase field is stable over the temperature range $T=1633-1640 \mathrm{~K}$ and equilibrium solidification occurs by the eutectic reaction, $L\left(+\mathrm{Al}_{2} \mathrm{O}_{3}\right)=\gamma+\beta$ $\left(+\mathrm{Al}_{2} \mathrm{O}_{3}\right)$ at $T=1640 \pm 1 \mathrm{~K}$ with a liquid composition of $24.8 \pm$ 0.2 at. $\% \mathrm{Al}$ (at an unknown $\mathrm{O}$ content). This behavior is inconsistent with the current $\mathrm{Ni}-\mathrm{Al}$ phase diagram in the vicinity of $\gamma^{\prime}-\mathrm{Ni}_{3} \mathrm{Al}$ and a new $\mathrm{Ni}-\mathrm{Al}$ phase diagram (projected from the $\mathrm{Ni}-\mathrm{Al}-\mathrm{O}$ system) was proposed based on these new results. This new $\mathrm{Ni}$-Al phase diagram provides a compelling explanation for some steady-state solidification structures that are routinely observed but are difficult to explain in terms of the current $\mathrm{Ni}-\mathrm{Al}$ phase diagram. If viewed objectively, this new phase diagram is consistent with all previously reported observations and provides a much simpler reaction scheme.

\section{Acknowledgements}

The funding for this work came from AFRL / MLLM, Materials for Air Breathing Propulsion Project and NASA Glenn Research Center's Low Emission Alternative Propulsion Project.

\section{References}

1. W. Alexander, N. Vaughan, Journal of the Institute of Metals, 1937, 61, 247.

2. A. Bradley, A. Taylor, Proc. Roy. Soc., 1937, A-159, 56.

3. J. Schramm, Z. Metallkunde, 1941, 33, 347.

4. R. Floyd, Journal of the Institute of Metals, 1951-52, 80, 551.

5. A. Taylor, R. Floyd, Journal of the Institute of Metals, 1952-53, 81, 25 .

6. F. Bremer, M. Beyss, E. Karthaus, A. Hellwig, T. Schober, J. Welter, H. Wenzl, J. of Crystal Growth, 1988, 87, 185.

7. F. Bremer, M. Beyss, H. Wenzl, phys. stat. sol. A, 1988, $110,77$.

8. K. Hilpert, D. Kobertz, V. Venugopal, M. Miller, F. Bremer, H. Nickel, Z. Naturforsch., 1987, 42a, 1327.

9. S. Dharwadkar, K. Hilpert, D. Kobertz, V. Venugopal, H. Nickel, High Temp. Sci., 1990, 28, 203.

10. L. Battezzati, M. Baricco, L. Pascale, Scripta Materialia, 1998, 39(1), 87.

11. J. Verhoeven, J. Lee, F. Laabs, L. Lones, J. Phase Equil., 1991, 12, 15.

12. J. Lee, J. Verhoeven, J. Phase Equilibria, 1994, 15, 136. 
13. J. Lee, J. Verhoeven, J. Crystal Growth, 1994, 142, 193.

14. J. Lee, J. Verhoeven, J. Crystal Growth, 1994, 143, 86.

15. J. Lee, J. Verhoeven, J. Crystal Growth, 1994, 144, 353.

16. O. Hunziker, W. Kurz, Acta mater., 1997, 45(12), 4981.

17. R. Cahn, P. Siemers, J. Geiger, P. Bardhan, Acta metall., 1987, 35(11), 2737.

18. F. Wei, M. Seiji, M. Yoshinao, Mechanical Properties Phase Transformations Multiphase Intermetallic Alloys: Proceedings Symposium Ed... Minerals Metals and Materials Society, Warrendale, PA, 1995, 207.

19. M. Hansen, K. Anderko, Constitution of Binary Alloys, McGraw-Hill, New York, 1958, 118.

20. P. Nash, M. Singleton, J. Murry, In Phase Diagrams of Binary Nickel Alloys, ASM International, Materials Pak, $\mathrm{OH}, 1991,3$.

21. H. Okamoto, Journal of Phase Equilibria, 1993, 14, 257.

22. Y. Du, N. Clavaguera, J. Alloys and Compounds, 1996, 237, 20.

23. I. Ansara, N. Dupin, H. Lukas, B. Sundman, J. Alloys and Compounds, 1997, 247, 20.

24. W. Huang, Y. Chang, Intermetallics, 1998, 6, 487.

25. F. Zhang, Y. Chang, Y. Du, S. Chen, W. Oates, Acta Materialia, 2003, 51, 207.

26. E. Copland, International Journal of Materials Research, 2006 8, 1108.

27. E. Kato, J. Mass Spectrom. Soc. Japan, 1993, 41(6), 297.

28. J. Tomiska, A. Neckal, International Journal of Mass Spectrometry and Ion Physics, 1983, 47, 223.

29. E. Copland, Scripta Met., 2007, 57(1), 21.

30. W. Boettinger, U. Kattner, Metall. Mater. Trans. A, 2002, 33A, 1779.

31. E. Copland, J. Phase Equilibria and Diffusion, online: http://www.springerlink.com/content/v02007j0x8k7255 $6 /$.

32. F. Elrefaie, W. Smeltzer, J. Electrochem. Soc. 1981, 128(10), 2237.

33. H. Wriedt, Bull. Alloy Phase Diagrams, 1985, 6(6), 548-553; 567-568.

34. J. Taylor, A. Dinsdale, Z. Metallkd., 1990, 81(5), 354.

35. G. N. Lewis, M. Randall, Thermodynamics (revised by K. S. Pitzer and L. Brewer) McGraw-Hill, New-York, 1961, 242-278.

36. C. H. P. Lupis, Chemical Thermodynamics of Materials, North-Holland, New-York, 1983. 97-112.

37. O. Kubaschewski, C. B. Alcock, Metallurgical Thermochemisty, ( $5^{\text {th }}$ Edition) Pergamon Press, Oxford, 1979, pp. 29-64.

38. J. Drowart, C. Chatillon, J. Hastie, D. Bonnell, Pure and Applied Chemistry, 2005, 77(4), 683.

39. A. Büchler, J. Stauffer: in Thermodynamics (IAEA Vienna, 1966) vol. 1, 271.

40. C. Chatillion, C. Senillou, M. Allibert, A. Pattoret, Rev. Sci. Instrum., 1976, 47(3), 334.

41. P. Morland, C. Chatillion, P. Rocabois, High Temp. and Materials Sci., 1997, 37, 167.

42. C. Chatillion, L. Malheiros, P. Rocabois, M. Jeymond, High Temp. High Pressures, 2002, 34, 213.
43. E. Copland, Thermodynamic Effect of Platinum Addition to $\beta-\mathrm{NiAl}$ : An Initial Investigation, NASA/CR-2005213330, NASA, Cleveland, OH, 2005.

44. E. Copland, Acta Materialia, 2007, 55, 4853.

45. E. Copland, J. Chem. Thermodynamics, 2006, 38, 443.

46. R. C. Paule, J. Mandel: National Bureau of Standards Special Publication 260-19, 1970.

Also published as: R. C. Paule, J. Mandel: Pure and Applied Chem., 1972, 31, 371.

47. L. V. Gurvich, I. V. Veyts, C. B. Alcock: Thermodynamic Properties of Individual Substances, English Version, Begell House, 1996.

48. M. W. Chase: NIST-JANAF Thermochemical Tables, $4^{\text {th }}$ Ed., American Chemical Society, 1998.

49. S. Nunoue, E. Kato, Metallurgical Transactions A, 1989, 20A, 975.

50. E. Kato, Journal of the Mass Spectrometry Society of Japan, 1993, 41(6), 297.

51. E. Copland, Int. J Materials Research, 2006, 97(8). 1108.

52. E. Copland, J. Chemical Thermodynamics, 2006, 38(4), 443.

53. N. Potter, M. Boyer, Fred, D. Hildenbrand, E. Murad, AD0715567, AFOSR 70-2311 TR, (1970).

54. L. Brewer and A. Searcy, J. Am. Chem. Soc., 1951, 73, 5308.

55. Y A Priselkov, Y A Sapozhnikov, A V Tseplyaeva, Izv. An SSSR Otd. Tekhn. Nauk. Metallurgiya I Toplivo, 1, (1959), 106.

56. D. Hildenbrand, SRI, personal communication, (December, 11 2007).

57. R. McDonald, J. Chem. and Eng. Data, 1967, 12, 115. 